Images in...

\title{
Fistulous connection between the left anterior descending coronary artery and pulmonary artery
}

\author{
A Zaidi, ${ }^{\text {R P Cowell }}$ \\ ${ }^{1}$ Department of Cardiology, Singleton Hospital, Swansea, UK \\ ${ }^{2}$ Department of Cardiology, Wrexham Maelor Hospital, Wrexham, UK
}

Correspondence to A Zaidi, dr_abbaszaidi@hotmail.com

\section{DESCRIPTION}

A 65-year-old woman who had presented with exertional breathlessness was found to have severe mitral regurgitation secondary to mitral valve prolapse, on transthoracic echocardiography. She was admitted for diagnostic coronary angiography, prior to mitral-valve surgery. The major epicardial coronary arteries were demonstrated to be free of disease, and left ventriculography confirmed severe mitral regurgitation. However, an anomalous arterial connection was seen to arise from either the left main coronary artery (LM) or the proximal left anterior descending coronary artery (LAD). In the left anterior oblique cranial projection, the anomalous vessel had the striking appearance of a 'Valentine Heart' (figure 1).

Subsequently, at the time of mitral valve surgery, the anomalous vessel was shown to be a fistulous connection between the LAD and the pulmonary artery (PA) and was ligated during the procedure.
Coronary arteriovenous fistulae are rare malformations, accounting for $0.2-0.4 \%$ of congenital cardiac anomalies. They may be associated with a continuous murmur or may be an incidental finding on coronary angiography. They may result in a 'steal' phenomenon causing ischaemic symptoms in the absence of occlusive coronary disease ${ }^{1}$ and in severe cases can lead to heart failure. ${ }^{2}$

Fistulous connections between the coronary arteries and the PA are well described in the literature. ${ }^{34}$ Successful surgical repair of coronary-pulmonary fistulae is also well documented. ${ }^{5} 6$

Due to the potential for serious clinical sequelae, some authors have advocated that all coronary arteriovenous fistulae should be corrected surgically or by transcatheter closure. ${ }^{7}$ This can easily be achieved at the time of surgery for concomitant cardiac conditions, although the optimal management strategy for isolated coronary fistulae remains unclear.

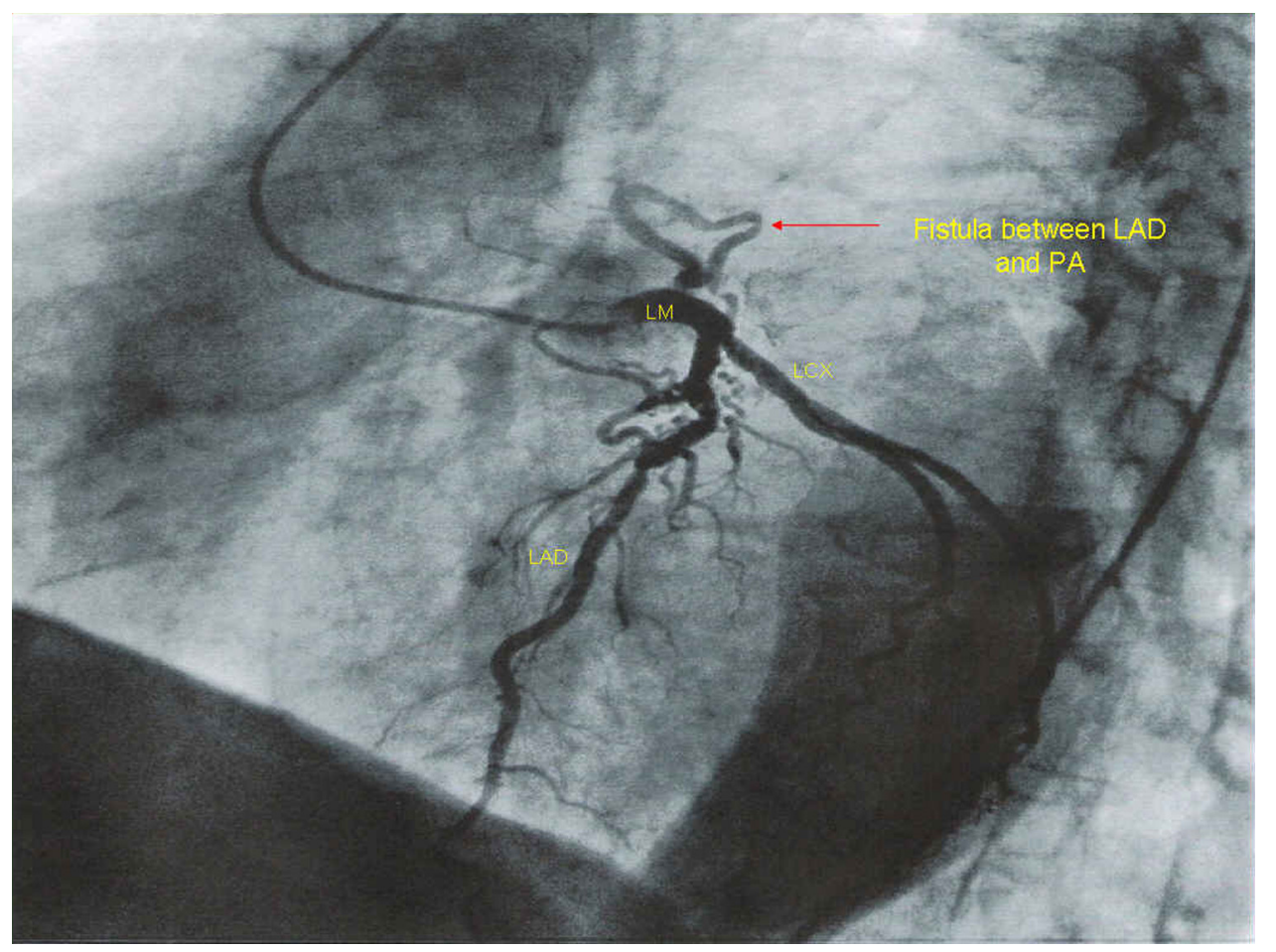

Figure 1 Left anterior oblique cranial projection of the left coronary circulation showing left main coronary artery (LM) bifurcating into the left anterior descending artery (LAD) and left circumflex artery (LCX). A fistulous connection can be seen to arise from the proximal LAD. 


\section{BMJ Case Reports}

Competing interests None.

Patient consent Obtained.

\section{REFERENCES}

1. Chang SM, Matangi MF. Unstable angina with coronary to pulmonary artery fistulae. Can J Cardiol 1987;3:220-2.

2. Yeboah J, Akosah K, Ailawadi G. Heart Failure due to coronary fistulas from the right and left coronary circulation into the right atrium. J Cardiovasc Med (Hagerstown) 2010;11:517-18.

3. Tanriverdi $\mathbf{H}$, Seleci D, Semiz E. Angiographic detection of the left anterior descending and the right coronary artery after fistulas into the pulmonary artery in a patient with rheumatic mitral stenosis. Int $J$ Cardiol 2006;109:139-41.

4. Schamroth C. Coronary artery fistula. J Am Coll Cardiol 2009;53:523.

5. Osawa H, Sakurada T, Sasaki J, et al. Successful surgical repair of a bilateral coronary-to-pulmonary artery fistula. Ann Thorac Cardiovasc Surg 2009;15:50-2.

6. Ozaki N, Wakita N, Inoue K, et al. Surgical repair of coronary artery to pulmonary artery fistula with aneurysms. Eur J Cardiothorac Surg 2009;35:1089-90.

7. Ata $\mathbf{Y}$, Turk T, Bicer M, et al. Coronary arteriovenous fistulas in the adults: natural history and management strategies. J Cardiothorac Surg 2009;4:62.

This pdf has been created automatically from the final edited text and images.

Copyright 2010 BMJ Publishing Group. All rights reserved. For permission to reuse any of this content visit http://group.bmj.com/group/rights-licensing/permissions. BMJ Case Report Fellows may re-use this article for personal use and teaching without any further permission.

Please cite this article as follows (you will need to access the article online to obtain the date of publication).

Zaidi A, Cowell RP. Fistulous connection between the left anterior descending coronary artery and pulmonary artery. BMJ Case Reports 2010; 10.1136/bcr.11.2009.2470, date of publication

Become a Fellow of BMJ Case Reports today and you can:

- Submit as many cases as you like

Enjoy fast sympathetic peer review and rapid publication of accepted articles

Access all the published articles

Re-use any of the published material for personal use and teaching without further permission

For information on Institutional Fellowships contact consortiasales@bmjgroup.com

Visit casereports.bmj.com for more articles like this and to become a Fellow 